\title{
Isolation and characterization of polymorphic microsatellite markers in Eurasian vulture Gyps fulvus
}

\author{
S. MIRA,${ }^{*}$ C. BILLOT,${ }^{*}+$ T. GUILLEMAUD,${ }^{*} \ddagger$ L. PALMA* and M. L. CANCELA* \\ *University of Algarve, CCMar, 8000-117 Faro, Portugal
}

\begin{abstract}
To obtain polymorphic molecular markers for population genetic and conservation studies in the Eurasian vulture Gyps fulvus populations, we screened a size-selected partial genomic library enriched for microsatellites with dinucleotide motifs. A total of five polymorphic markers were obtained. The number of alleles ranged from two to nine and the observed and expected heterozygosity were very similar. These markers will be very useful for studying population structure and to evaluate conservation programmes.
\end{abstract}

Keywords: Eurasian Vulture, Gyps fulvus, microsatellite

During the last century the Eurasian vulture Gyps fulvus was widely distributed in the western paleartic, particularly around the Mediterranean area (Sarrazin et al. 2000). However a dramatic decline occurred around the end of the 19th century and beginning of the 20th century, leading to the conservation of Eurasian Vulture populations in many countries particularly in Europe (Sarrazin et al. 2000).

Population genetics play an important role in the development of conservation programmes for endangered species. Recently the use of microsatellites as molecular markers has proved to be an excellent tool for genetic studies (Jarne \& Lagoda 1996). Here we present the development of microsatellite markers that can be useful for developing and monitoring conservation and reintroduction programmes of $G$. fulvus.

Genomic DNA was extracted from blood samples following the protocol described in Seutin et al. (1991) and used to construct a partial enriched genomic library following protocols slightly modified from Edwards et al. (1996) and Kijas et al. (1994). DNA was digested with the restriction enzyme Sau3AI and the resulting fragments, ranging from 200 to $800 \mathrm{bp}$, were ligated into annealed Sau3AI adaptors (AdapF: 5'-CTCTTGCTTACGCGTGGACTC-3'

Correspondence: M. Leonor Cancela, Fax: (+ 351) 289 818353; E-mail: lcancela@ualg.pt

+Present address: CIRAD-Biotrop, Avenue. Agropolis, F-34398, Montpellier Cedex-5, France. ‡Present address: UMR ROSE, INRA, BP 2078, 06606 Antibes cedex, France and AdapR: 5'-GATCGAGTCCACGCGTAAGCAAGAGCACA-3'). After denaturation, single stranded DNA was enriched through hybridization with 5'-biotinylated, 3'aminated $(\mathrm{CT})_{15}$ oligonucleotide bound to streptavidincoated magnetic spheres (Magnesphere, Promega, Madison, Wi, USA), following Koblízková et al. (1998). The enriched DNA was then used as template for amplification using the polymerase chain reaction (PCR) with AdapF as the primer to recover double stranded DNA fragments. The resulting purified PCR product ( $8 \mathrm{ng}$ ) was directly ligated overnight at $4{ }^{\circ} \mathrm{C}$ into pGEM-T easy vector (50 ng) (Promega, Madison, Wi, USA) using 3 units of T4 ligase (Promega, Madison, $\mathrm{Wi}$ ). One tenth of the ligation product was used to transform $100 \mu \mathrm{L}$ of supercompetent cells (X11-Blue $\mathrm{MRF}^{\prime}$, Stratagene, La Jolla, CA). Libraries were screened using PCR performed directly on the lysed bacteria, using a (CT) ${ }_{10}$ primer and a plasmid primer (forward or reverse), according to Waldbieser (1995).

Out of 800 bacterial clones, 172 gave a positive result. 45 positive clones were sequenced according to the dideoxy chain termination method (Sanger et al. 1977) and 22 were found to contain a microsatellite. For 10 of the clones containing at least four consecutive repeated motives and where the position of the microsatellite would allow, primers were designed for the flanking regions using the PRIMER 3.0 software (Rozen \& Skaletsky 1997). Polymorphism was tested on 10 juvenile vultures migrating through Portugal and held for rehabilitation in the Natural Park of Ria Formosa (two individuals in 1994 and eight in 1999). PCR analysis was performed in a total volume of 
Table 1 Gyps fulvus microsatellite loci. The locus, accession number, number of motif repeat, primers, and size of the amplification product from the clones are indicated, annealing temperature, $\mathrm{MgCl}_{2}$ concentrations, number of alleles obtained along with the observed $\left(H_{\mathrm{O}}\right)$ and nonbiased expected $(\mathrm{Hnb})$ heterozygosities are also indicated. Numbers of alleles and heterozygosities are based on a sample of 10 juveniles migrating through Portugal

\begin{tabular}{|c|c|c|c|c|c|c|c|c|c|}
\hline Locus & $\begin{array}{l}\text { Accession } \\
\text { number }\end{array}$ & Motif & $\begin{array}{l}\text { Primer }\left(5^{\prime} \rightarrow 3^{\prime}\right) \\
\text { F: Forward; R: Reverse }\end{array}$ & $\begin{array}{l}\text { Size } \\
(b p)\end{array}$ & $\begin{array}{l}\text { Anneal. } \\
\text { Temp }\left({ }^{\circ} \mathrm{C}\right)\end{array}$ & $\begin{array}{l}\mathrm{MgCl}_{2} \\
(\mathrm{mM})\end{array}$ & $\begin{array}{l}\text { No of } \\
\text { alleles }\end{array}$ & $H_{\mathrm{O}}$ & $H n b$ \\
\hline Gf11A4 & AY035858 & $(\mathrm{CTCTT})_{17}$ & $\begin{array}{l}\text { F: GATCCCTTCCAACCGAAAAT } \\
\text { R: TGGTGACCAACGGAAGTGTG }\end{array}$ & 148 & 50 & 2 & 7 & 1.00 & 0.85 \\
\hline Gf3H3 & AY035859 & $(\mathrm{CT})_{12}$ & $\begin{array}{l}\text { F: GTAGAATAATTTGCTCCTGG } \\
\text { R: GTGAAGGCACCTCATAGACA }\end{array}$ & 139 & 48 & 2.5 & 5 & 0.70 & 0.76 \\
\hline Gf3F3 & AY035860 & $(\mathrm{CT})_{10}$ & $\begin{array}{l}\text { F: GATCTTTCCCCTTCTGTG } \\
\text { R: TTCGTGCAGTGATGCTGGTG }\end{array}$ & 180 & 52 & 2.5 & 2 & 0.30 & 0.39 \\
\hline Gf8G1 & AY113692 & $(\mathrm{CT})_{8} \mathrm{C}(\mathrm{TC})_{2}$ & $\begin{array}{l}\text { F: TGAGCAGGTGAGTCCAGAAG } \\
\text { R: GCTCTCCTGTCATCTTGCAT }\end{array}$ & 271 & 50 & 2 & 2 & 0.50 & 0.39 \\
\hline Gf9C1 & AY035855 & $\begin{array}{l}(\mathrm{TC})_{10+}(\mathrm{CT})_{9} \mathrm{C} \\
(\mathrm{CA})_{5} \mathrm{~T}(\mathrm{AC})_{4}\end{array}$ & $\begin{array}{l}\text { F: GGTGGACATTACATACACTG } \\
\text { R: CAAGGAATCTGGACTACTAA }\end{array}$ & 255 & 50 & 2 & 9 & 0.80 & 0.87 \\
\hline
\end{tabular}

$10 \mu \mathrm{L}$ containing $10-50 \mathrm{ng}$ of DNA, $20 \mathrm{~mm}$ Tris- $\mathrm{HCl}$ (PH 8,4), $50 \mathrm{~mm} \mathrm{KCl}$, between 2.0 and $2.5 \mathrm{~mm} \mathrm{MgCl}_{2}, 10 \mu \mathrm{M}$ dATP, $60 \mu \mathrm{M}$ of each of the other dNTPs, $0.5 \mu \mathrm{M}$ of each primer, 0.5 unit of Taq DNA polymerase (Gibco BRL, Life Technologie Inc., Gaithersburg, MD) and $0.08 \mu \mathrm{L}[\alpha-$ $35 \mathrm{~S}] \mathrm{dATP}(12.5 \mathrm{mCi} / \mathrm{mL}, 1250 \mathrm{Ci} / \mathrm{nmol})$. Reactions were conducted in a Stratagene Robocycler (Stratagene Cloning Systems, La Jolla, CA) and consisted of a first denaturation step at $94^{\circ} \mathrm{C}$ for $4 \mathrm{~min}$, followed by 30 cycles of denaturing for $45 \mathrm{~s}$ at $94{ }^{\circ} \mathrm{C}$, annealing for $45 \mathrm{~s}$ at $48^{\circ} \mathrm{C}$ up to $52^{\circ} \mathrm{C}$ (depending on the locus, see Table 1), and extension for 45 s at $72{ }^{\circ} \mathrm{C}$. A final extension period of $5 \mathrm{~min}$ at $72{ }^{\circ} \mathrm{C}$ was performed. PCR products were size fractionated over a denaturing $6 \%$ acrylamide-bisacrylamide gel and visualized using autoradiography.

Of the 10 microsatellites isolated five corresponded to polymorphic loci exhibiting from two to seven alleles (Table 1). These molecular markers were also tested on genomic DNA from Bonelli's eagle (Hieraaetus fasciatus) but only locus Gf3H3 was found to be polymorphic with 2 alleles; the rest being monomorphic.

Observed and expected heterozygosities calculated using GENETIX (Belkhir et al. 2000), were similar (Table 1), and no linkage disequilibrium was detected between each pair of locus.

In conclusion, we developed five microsatellite markers for the Eurasian Vulture G. fulvus that are appropriate molecular tools for population genetic studies and for designing strategies in conservation and reintroduction projects.

\section{Aknowledgements}

This work was partially funded by the Portuguese Science and Technology Foundation (FCT) project PRAXIS/BIA/132/96. CB and TG were recipients of postdoctoral fellowships from FCT (BPD 18902/98 and BPD 4470/96, respectively). SM is recipient of a PhD fellowship from FCT (BD 3163/2000). The authors thank Martin Billigham for critical reading of the manuscript.

\section{References}

Belkhir K, Borsa P, Goudet J, Chikhi L, Bohnomme F (2000) Genetix Logiciel sous windows TM, pour la Génétique des Populations. At http://www. University-montp2.fr/ genetix/genetix.htm.

Edwards KJ, Barker JHA, Dal A, Jones C, Karp A (1996) Microsatellite libraries enriched for several microsatellite sequences in plants. Biotechnique, 20, 758-760.

Jarne P, Lagoda JL (1996) Microsatellites, from molecules to population and back. Trends in Ecology and Evolution, 11, 424429.

Kijas JMH, Fowler JCS, Garbett CA, Thomas MR (1994) Enrichment of microsatellites from the citrus genome using biotinylated oligonucleotide sequences bound to streptavidin-coated magnetic particles. Biotechniques, 16, 657-662.

Koblízková A, Dolezel J, Macas J (1998) Subtraction with 3' modified oligonucleotides eliminates amplification artifacts in DNA libraries enriched for microsatellites. Biotechniques, 25, 32-38.

Rozen S, Skaletsky HJ (1997) PRIMER3. Code available at http:// www-genome.wi.mit.edu/genome_software/other/primer3.html.

Sanger F, Nicklen S, Coulson AR (1977) DNA sequencing with chain-terminating inhibitors. Proceedings of the National Academy of Sciences of the USA, 74, 5463-5467.

Sarrazin F, Arthur CP, Bangnolini C (2000) Re-introduction of griffon vultures in France. Re-Introduction News, Special Bird Issue (eds Soorae PS, Seddon PJ) 19, pp. 50-52. IUCN/SSC UAE, Abu Dhabi, United Arab Emirates.

Seutin G, White BN, Boag PT (1991) Preservation of avian blood and tissue samples for DNA analyses. Canadian Journal of Zoologie, 69, 82-90.

Waldbieser GC (1995) PCR-Based identification of AT-Rich triand tetranucleotide repeat loci in an enriched plasmid library. Biotechniques, 19, 742-744. 